\title{
Aspects of the biology of the Atlantic Midshipman, Porichthys porosissimus (Teleostei, Batrachoididae): an important by-catch species of shrimp trawling off southern Brazil
}

\author{
Marcelo Vianna '; Acácio R. G. Tomas ${ }^{1} \&$ José R. Verani ${ }^{2}$ \\ 'Instituto de Pesca \\ (Av. Bartolomeu de Gusmão, 192, 11030-906 Santos, SP, Brasil) \\ ${ }^{2}$ Universidade Federal de São Carlos \\ (Caixa Postal 676, 13565-905 São Carlos, SP, Brasil)
}

- Abstract: Trawl fishing for pink shrimp (Farfantepenaeus brasiliensis and F. paulensis) catches large quantities of by-catch fish, discarded due to their having no commercial value. As these species have rarely been studied, the impact of fisheries on these populations is not known. This contribution studies the biology of a species of no commercial value, the Atlantic midshipman Porichthys porosissimus. The last haul from a commercial trawler, operating on the northern coast of São Paulo State and the southern coast of Rio de Janeiro State, was preserved (from being discarded) and identified at the species level. It was observed that this fishery affects the juvenile population which is influenced by the seasonal variation of the water masses. Growth parameters were estimated: $\mathrm{L} \infty=37.0 \mathrm{~cm}, \mathrm{~K}=0.285$ year $^{-1}$. Instantaneous mortality coefficients were estimated: $\mathrm{Z}=2.14, \mathrm{M}=0.63, \mathrm{~F}=1.51, \mathrm{~S}=11.8$ and $E=0.71$. Considering the intensive activity of the shrimp trawl fleet operating in this area, the deleterious action of trawling is considered as of high impact. The stock management measures applied for pink shrimp are without effect regarding $P$. porosissimus, which has its spawning period before the closed season and its recruitment peak after it. The results show overfishing and the need to apply measures to reduce trawling action, such as adequate policies, introduction of selectivity devices and the creation of exclusion zones for trawl fishing.

- Resumo: A pesca de arrasto para a captura do camarão-rosa (Farfantepenaeus brasiliensis e $F$. paulensis) captura grande quantidade de peixes considerados fauna acompanhante que são descartados por não possuírem valor comercial. Assim, pouco aparecem em trabalhos de biologia pesqueira com dados de desembarque, sendo a ação pesqueira sobre estas populações pouco conhecida. Neste estudo, um arrasto mensal de um barco de pesca foi desembarcado sem que nada do material capturado fosse descartado. Analisou-se Porichthys porosissimus do qual foram avaliados aspectos biológicos e pesqueiros. Estimou-se, para a espécie: $\mathrm{L} \infty=37,0$ $\mathrm{cm}, \mathrm{K}=0,285$ ano $^{-1}, \mathrm{Rn}=180\left(\mathrm{x} 10^{-3}\right), Z=2,14, \mathrm{M}=0,63, \mathrm{~F}=1,51, \mathrm{~S}=11,8$ e $\mathrm{E}=0.71$. Embora não intencional, a pesca age principalmente em jovens e ocorre durante o ano todo, sendo influenciada pela sazonalidade das massas d'água. Considerando a frota operante na área, o efeito do arrasto é considerável, já que a taxa de aproveitamento é nula. As medidas de proteção de estoque aplicadas ao camarão-rosa não são efetivas para $P$. porosissimus, que apresenta o período de desova anterior à época do defeso e o pico de recrutamento pesqueiro posterior. Os resultados indicam sobrepesca da população estudada sendo necessário medidas de modo a diminuir a ação deletéria do arrasto, como a adequação da legislação, uso de dispositivos de seletividade e a criação de zonas de exclusão de arrasto.

- Descriptors: Porichthys porosissimus, By-catch, Shrimp trawls, Mortality: São Paulo coast.

- Descritores: Porichthys porosissimus, Fauna acompanhante, Pesca de arrasto de camarão, Mortalidade: Litoral de São Paulo. 


\section{Introduction}

The south-eastern region has one of the widest continental shelves on the Brazilian coast, which allows the trawl fisheries of several shrimp and groundfish species. Most of the fishing boats operate between 4 and 90 meter depths. Due to the low selectivity of the trawlers and the high diversity of catches, shrimp trawlers are considered responsible for the greater part of the by-catch. By definition, by-catch comprises any individual, of any size or species, caught together with the target species. The species composition of the bycatch has some interaction with the target species, e.g., the shared spatial distribution. Only a portion of the total catch is landed and sold (either as a single category, or grouped by similarity or in a groups of several species). The others are discarded because they have no commercial value. They are composed of immature and/or small individuals (Alverson et al., 1994) and are not included in the catch statistics, which diminishes the efficiency of the catch control (Coelho et al., 1986), and is harmful to several species and population strata (Haimovici \& Mendonça, 1996).

Among shrimp trawl fisheries, finfish are the most abundant and of economic importance (Coelho et al., op. cit.). Despite the large number of species, few of them constitute a large biomass or number of individuals. Though this is well known, the biology of fish species along the northern coast of São Paulo State is further harmed. Regional studies on the biological data of species fished will contribute to the formulation of fishery management plans, including fishery policies. The updating and monitoring of this information on the by-catch species will allow some estimate of the population parameters to be made, such as the von Bertalanffy growth curve, as also of their reproductive activities. For Haimovici \& Macieira (1981), quantifying effects of discarding on fish stocks may be evaluated by growth studies, mortality, distribution and abundance of those species.

The study area has already been investigated intensively by the Oceanographic Institute of the University of São Paulo (Rossi-Wongtschowski \& Paes, 1993). The opportunity to compare the catch composition obtained from scientific investigation with commercial catches over a period of 10 years, is convenient for checking occasional oscillations of the population parameters of the groundfish species. Castro-Filho et al. (1987) described the hydrodynamic complexity of the region, showing that the cold water mass (South Atlantic Central Water) has a decisive role in the biological productivity of the coastal region during the summer season.

This contribution shows some aspects of the fishery biology of the Atlantic midshipman, Porichthys porosissimus (Valenciennes, 1837) (Teleostei,
Batrachoididae), to show the catch composition, growth and mortality estimates, as well as reproductive activities and the impact of the fisheries on the population sampled.

\section{Material and methods}

The Atlantic midshipman, Porichthys porosissimus, of the region was formerly studied by Peria (1995) using data obtained from scientific cruises conducted during 1984/85. The biological sampling was made once a month over the 14-month period from July 1995 to August 1996 on commercial shrimp trawlers. The first two months were used to adapt the methodology and so these data were not used to estimate the biological parameters. Because the bycatch information of shrimp trawling in the region was limited to the coastal region along the $15 \mathrm{~m}$ isobath, the samples were obtained through catches from over $30 \mathrm{~m}$ deep of the pink shrimp (Farfantepenaeus brasiliensis and $F$. paulensis) fisheries. Considering the high mobility of the fishing boats, the catch stations were represented by the nearest geographical place corresponding to a central point of the trawling area.

Data were provided by a haul made from a 17 $\mathrm{m}$ double-outrigger otter trawl boat on the northern coast of São Paulo State and/or southern coast of Rio de Janeiro State (only one of the two nets was analysed). The dimensions of the net used were $25 \mathrm{~mm}$ mesh size from opposite knots on codend; length of $18 \mathrm{~m}$ on the upper side of the net and $20 \mathrm{~m}$ on the bottom. The towing speed was maintained around 2.5 knots and each haul lasted between two and three hours (Tab. 1). The entire catch was landed (no discarding was done). To avoid losing data during the 90-day closed season for pink shrimp fisheries (February $15^{\text {th }}$ to May $15^{\text {th }}$ ), samples were obtained with a sea-bob shrimp (Xiphopenaeus kroyeri) fishery net $(9 \mathrm{~m}$ in length, $6 \mathrm{~m}$ on the bottom side of the net and $15 \mathrm{~mm}$ mesh size on codend), operating at an average depth of $23 \mathrm{~m}$. Although there are some differences in design and mesh size among nets employed for pink and sea-bob shrimps, it is supposed that after some time of operation their selectivity (i.e., retained size of individuals) may be considered similar. No further considerations regarding fish escaping due to different shapes (and, consequently, tow ratios) of the nets are raised here.

All landings were done at Ubatuba city. Data of the fishing area, depth and duration of haul were registered by interviewing the master fishermen. Catches were separated and weighed first as a whole (by species) and then individually. Each specimen had its total length (in $0.5 \mathrm{~cm}$ ) and total weight (in $1 \mathrm{~g}$. after drying in paper) registered. Total number $(\mathrm{N})$, total biomass and length frequency were 
also obtained. The relative numerical abundance (RNA) was based on the number of individuals per hour of haul (ind/h). Catch-per-unit-of-effort (CPUE) was obtained by the ratio of total weight (in grams) per hour of haul $(\mathrm{g} / \mathrm{h})$. CPUE values must be seen as exclusively for purposes of comparison between the target species and $P$. porosissimus. All data were grouped bimonthly. The composition and population structure were obtained by analysing the number of individuals per length class for the sex groupings.

Several methods were used for the estimates of growth parameters. Taylor's expression (Pauly \& Martosubroto, 1980), L $\infty=\mathrm{L} \max / 0.95$ was used, where Lmax was obtained through data gathered in this study, from scientific literature and unpublished data furnished by other colleagues in the same area. Then Wetherall's method (1986, as modified by Pauly, 1986), available in FISAT package (FAOICLARM Stock Assessment Tools), and the ELEFAN I routine (Pauly \& David, 1981) were used for data analysis. Considering, first, the option for oscillatory growth, the estimates of the oscillation factor $(C)$ and the winter point (WP) were made, based on the seasonal influence of South Atlantic Central Water $(\mathrm{SACW})$ in the area and on the seasonal temperature variability which varies $\left(5.5^{\circ} \mathrm{C}\right.$, CastroFilho et al., 1987, or $4.5^{\circ} \mathrm{C}$, Rocha, 1990), as between winter and summer, thus obtaining $\mathrm{C}$ estimates of between 0.45 and 0.55 . Taking December as the coldest water month (due to SACW), WP was estimated at 0.91. All samples (except those for March and April) were grouped bimonthly and the files generated by the smoothing routine were refined by running average. Values of $L \infty$ and $K$ were chosen, assuming the goodness of fit index (Rn) with biological significance for the species, considered as indicative of the estimate of $L \infty$ obtained by former methods. For the same $\mathrm{Rn}$ values, the highest values for $\mathrm{K}$ and the lowest for $\mathrm{L} \infty$ were chosen, considering that the method overestimates $L_{\infty}$ (and consequently underestimates K) (Isaac-Nahum, 1989).

The growth performance index $\phi^{\prime}$ (Munro \& Pauly, 1983) $\left(\phi^{\prime}=\log \mathrm{K}+2 \log \mathrm{L} \infty\right)$ was applied to $\mathrm{K}$ and $L \infty$ values estimated by ELEFAN I. If differences occurred in $\phi^{\prime}$ values, they were rejected (Sparre \& Venema, 1992). The estimates of $L \infty$ and $K$ were also made taking non oscillatory growth ( $\mathrm{C}$ and WP equal to zero) into consideration.

The length-weight relationship (LWR) was calculated by the power equation $\left(\mathrm{W}_{t}=a L_{t}^{b}\right)$, after the $\log$-transformation of $\mathrm{W}_{t}$ and $\mathrm{L}_{t}$, and using the least square method (Sparre \& Venema, 1992). The $t$ test (Zar, 1984) was applied to verify the hypothesis of $b=3.0\left(\mathrm{H}_{0}\right)$, which defines the type of growth (as alometric or isometric).

The relative condition factor $(\mathrm{Kn})$ was calculated $\left(\mathrm{Kn}=\mathrm{W}_{\mathrm{t}} / \mathrm{W}_{\mathrm{e}}\right)$ by using expected weight $\left(\mathrm{W}_{\mathrm{e}}\right)(\mathrm{LeCren}, 1951)$ for a certain length $\left(\mathrm{W}_{\mathrm{e}}=\mathrm{a} \mathrm{L}_{\mathrm{t}}^{\mathrm{b}}\right)$, allowing the comparison of statistical values of $\mathrm{Kn}$ with 1.0. $\mathrm{Kn}$ values were estimated individually (excluding juveniles), and bimonthly averages and their respective confidence intervals (CI; $\alpha=0.05$ ) obtained. The cut-off length attributed to maturity for $P$. porosissimus was $15.5 \mathrm{~cm}$, based on the gonadal observations. The $t$-test (Zar, 1984) was applied to verify if values of bimonthly averages of Kn were equal to 1.0 .

Fishery recruitment was estimated graphically by length class frequency distributions. The relationship between target species (pink shrimp) catches and midshipman catches was evaluated using bimonthly values of CPUE for each one. Although the trawl nets for pink and sea-bob shrimps had different designs, after some minutes of trawling their selectivity may be considerably similar.

Table 1. General data of fisheries samples to this study in southern Brazil.

\begin{tabular}{|c|c|c|c|c|c|}
\hline Sample & Coordinates & Month & $\begin{array}{l}\text { Depth } \\
\text { (m) }\end{array}$ & $\begin{array}{c}\text { Beginning trawl } \\
\text { time }(\mathrm{h})\end{array}$ & $\begin{array}{c}\text { Duration of } \\
\text { trawl }(\mathrm{h})\end{array}$ \\
\hline I & $23^{\circ} 48^{\prime} \mathrm{S} / 45^{\circ} 0 \mathrm{I}^{\prime} \mathrm{W}$ & July/95 & 45 & $02: 00$ & 5.0 \\
\hline II & $23^{\circ} 40^{\prime} \mathrm{S} / 44^{\circ} 53^{\prime} \mathrm{W}$ & Aug/95 & 43 & 03:00 & 4.0 \\
\hline III & $23^{\circ} 41^{\prime} \mathrm{S} / 45^{\circ} 02 \mathrm{~W}$ & Sept/95 & 41 & $01: 00$ & 5.0 \\
\hline IV & $23^{\circ} 36^{\prime} \mathrm{S} / 45^{\circ} 01^{\prime} \mathrm{W}$ & Oct/95 & 37 & $02: 00$ & 4.0 \\
\hline V & $23^{\circ} 21^{\prime} \mathrm{S} / 44^{\circ} 32^{\prime} \mathrm{W}$ & Nov/95 & 35 & $03: 30$ & 4.0 \\
\hline VI & $23^{\circ} 38^{\prime} \mathrm{S} / 45^{\circ} 04^{\prime} \mathrm{W}$ & $\operatorname{Dec} / 95$ & 35 & $01: 30$ & 4.0 \\
\hline VII & $23^{\circ} 28^{\prime} \mathrm{S} / 44^{\circ} 55^{\prime} \mathrm{W}$ & $\operatorname{Jan} / 96$ & 31 & $03: 30$ & 3.5 \\
\hline VIII & $23^{\circ} 27 \mathrm{~S} / 44^{\circ} 45^{\prime} \mathrm{W}$ & Feb/96 & 37 & $02: 30$ & 4.0 \\
\hline IX & $23^{\circ} 25^{\prime} \mathrm{S} / 44^{\circ} 52^{\prime} \mathrm{W}$ & $\operatorname{Mar} / 96$ & 22 & $11: 00$ & 3.0 \\
\hline$x$ & $23^{\circ} 26^{\prime} \mathrm{S} / 44^{\circ} 52^{\prime} \mathrm{W}$ & Apr/96 & 24 & $10: 00$ & 2.0 \\
\hline $\mathrm{XI}$ & $23^{\circ} 26^{\prime} \mathrm{S} / 44^{\circ} 35^{\prime} \mathrm{W}$ & Mav/96 & 51 & $02: 00$ & 4.0 \\
\hline XII & $23^{\circ} 42^{\prime} \mathrm{S} / 45^{\circ} 06^{\prime} \mathrm{W}$ & June/96 & 35 & $01: 30$ & 4.0 \\
\hline XIII & $23^{\circ} 38^{\prime} \mathrm{S} / 45^{\circ} 01^{\prime} \mathrm{W}$ & July/96 & 42 & $01: 00$ & 6.0 \\
\hline XIV & $23^{\circ} 25^{\prime} \mathrm{S} / 44^{\circ} 40^{\prime} \mathrm{W}$ & Aug/96 & 41 & $02: 30$ & 4.0 \\
\hline
\end{tabular}


The total mortality ( $Z$ ) estimates were made using the equations of Beverton \& Holt (1956) $(Z=K$ $\left.\left[\left(L_{\infty}-L^{\prime}\right) /\left(L m-L^{\prime}\right)\right]\right)$ and of Ssentengo \& Larkin (1973) $\left(Z=(n K) /\left\{(n+1) \ln \left[\left(L_{\infty}-L^{\prime}\right) /(L \infty-L m)\right]\right\}\right)$, where $L^{\prime}$ is the length at which $100 \%$ of individuals are vulnerable to fishery and $\mathrm{Lm}$ the average length of all individuals larger than L'. The catch curve was also obtained using the FISAT program. Natural mortality (M) was estimated by Pauly's empirical equation ( $\log \mathrm{M}$ $=0.0066-0.279 \log \mathrm{L} \infty+0.6543 \log \mathrm{K}+0.4634 \log$ T) (Pauly, 1980), where habitat temperature (T) was considered to be $18.2{ }^{\circ} \mathrm{C}$. The final estimate for $Z$ was admitted as the average of all estimated values and then applied to obtain an estimate for fishery mortality $(F)$, stock exploitation ratio (E) and survival rate (S) using the following equations: $Z=F+M ; E=F / Z ; S=e^{-Z}$.

\section{Results}

Analysis of data was made based on the 2,897 individuals of Porichthys porosissimus, from all the samples collected over the 14-month period with a biomass of $99.6 \mathrm{~kg}$. The highest values of CPUE and RNA (Fig. 1) were registered for November-December and the lowest in July-August. Due to the pink shrimp closed season, the values for March-April were not taken into consideration

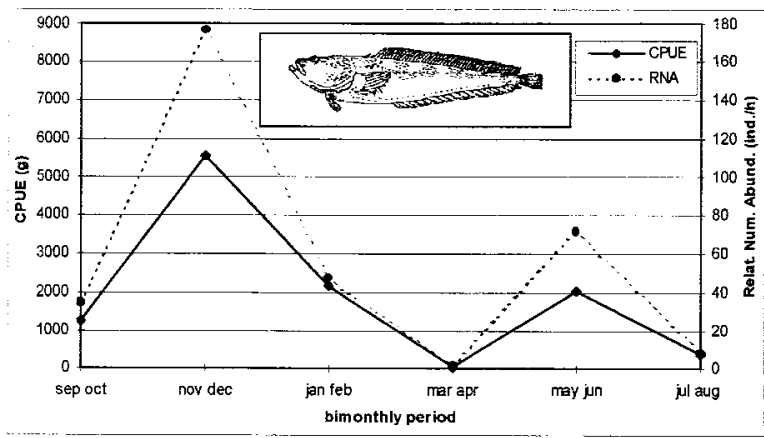

Fig. 1. Bimonthly catch per unit of effort (CPUE g/h) and relative abundance in number (ind./h) to Porichthys porosissimus in southern Brazil.

The pink shrimp presented the highest CPUE in July-August and the lowest in January-February, remaining constant the period from May to December (average close to $1,600 \mathrm{~g} / \mathrm{h}$ ) (Fig. 2).

The length range of the Atlantic midshipman was from 2.5 to $29.0 \mathrm{~cm}$. By analysing the bimonthly length frequency distribution (Fig. 3), the $16.0 \mathrm{~cm}$ class may be considered as the recruitment class, beginning in May-June and attaining its peak in July-August. In September-October the small individuals were present in large numbers, indicating a possible continued recruitment as from July-August (Fig. 4).

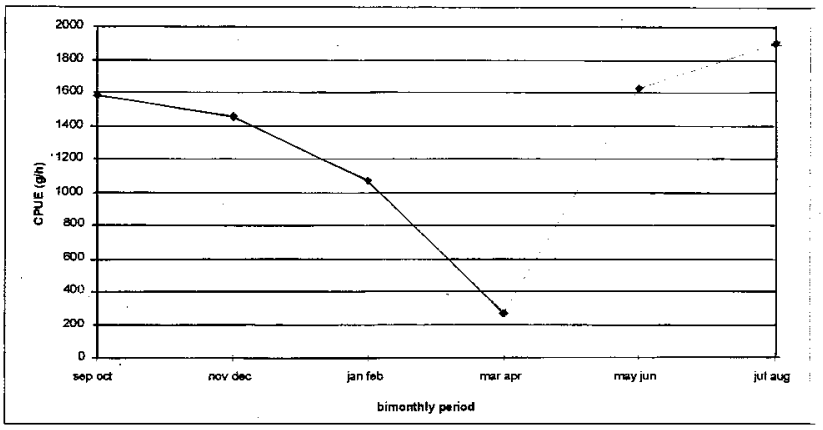

Fig. 2. Bimonthly catch per unit of effort (CPUE $g / h$ ) to the pink shrimp (Farfantepenaeus brasiliensis and $F$. paulensis) in southern Brazil.

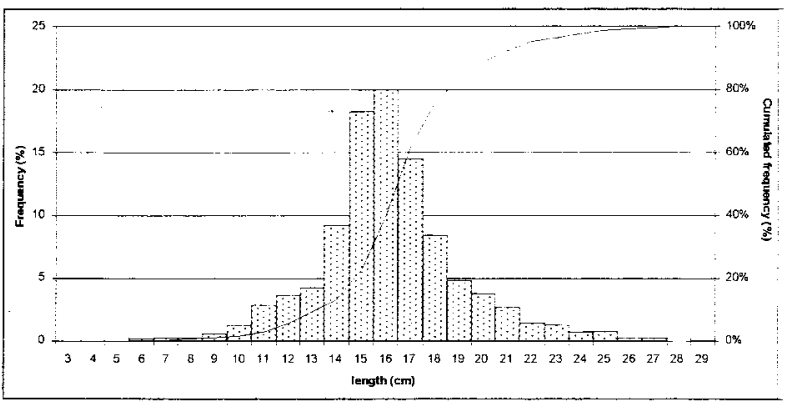

Fig. 3. Distribution of classes of total length frequencies of Porichthys porosissimus in southern Brazil.

The largest specimen registered in the literature measured $32.0 \mathrm{~cm}$ (Figueiredo \& Menezes, 1978) and this value was considered as Lmax, generating an estimated $\mathrm{L} \infty$ of $33.7 \mathrm{~cm}$. The estimate for L $\infty$ by Wetherall's method was $33.37 \mathrm{~cm}$ $(\mathrm{r}=-0.964)$. The ELEFAN I estimates for growth parameters are presented on Table 2. These values indicated six age classes (Fig. 5). Estimates from non oscillatory were smaller than those from oscillatory growth. The ELEFAN I values were higher than those given by other methods, but the tendency to underestimate $\mathrm{L} \infty$ values deserves mention (IsaacNahum, 1989).

The length-weight relationship of the Atlantic midshipman was expressed by the equation: $\mathrm{W}_{\mathrm{t}}=0.00498 \mathrm{~L}_{\mathrm{t}}^{3.148}\left(\mathrm{r}^{2}=0.941\right)$ and the $t$ test for parameter $b$ confirms the growth with positive alometry (calculated $t=8.398>$ critical $t, \mathrm{p}<$ $0.05)$. The relative condition factor $(\mathrm{Kn})$ for the species presented values higher than 1.0, considering significance tests for three bimonthly periods (September/October, January/February, July/August) (Fig. 6 and Tab. 3). Instantaneous mortality coefficients, exploitation rate and survival rate are shown in Table 4. 


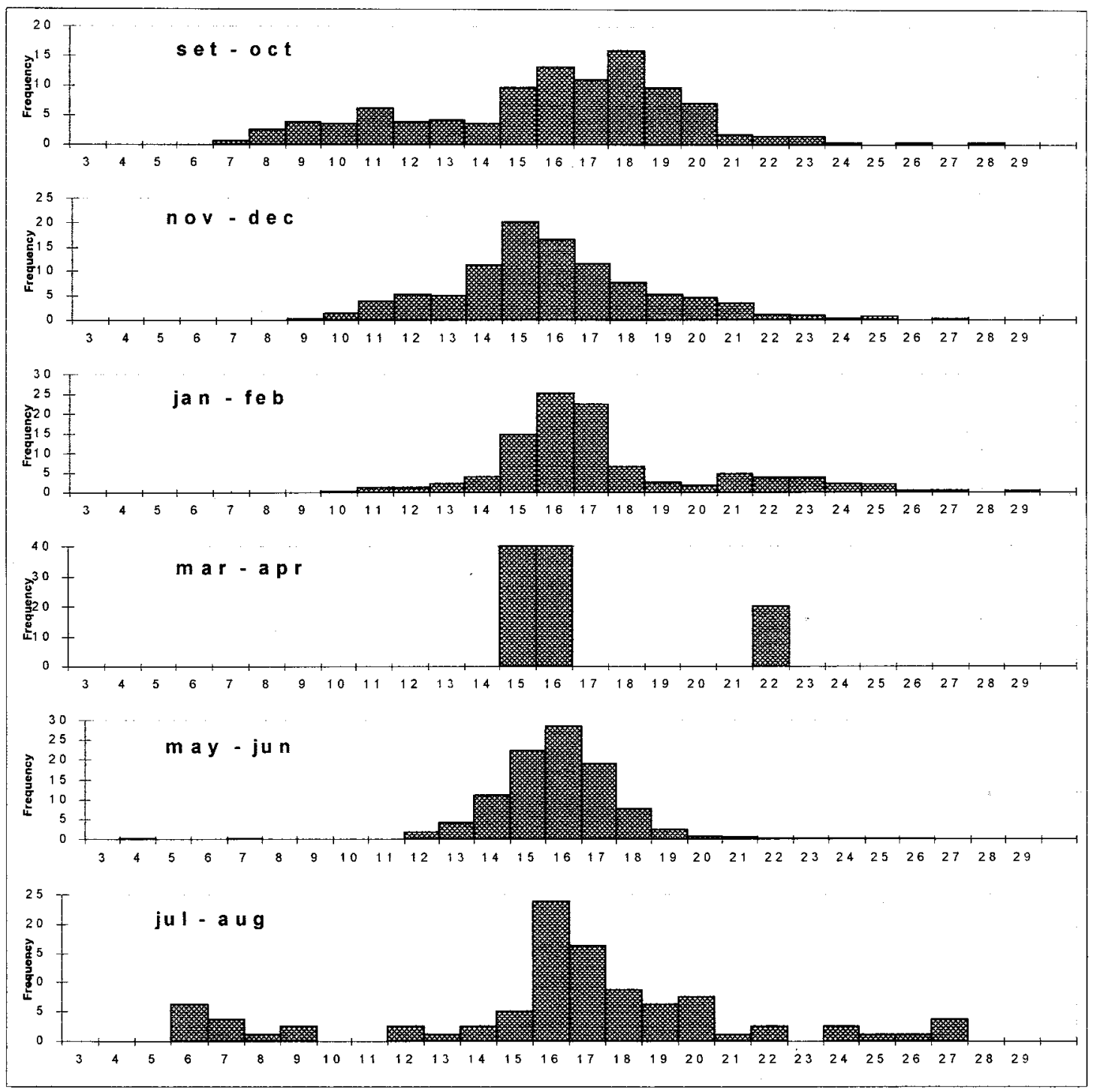

Fig. 4. Bimonth distribution of classes of total length frequencies of Porichthys porosissimus in southern Brazil.

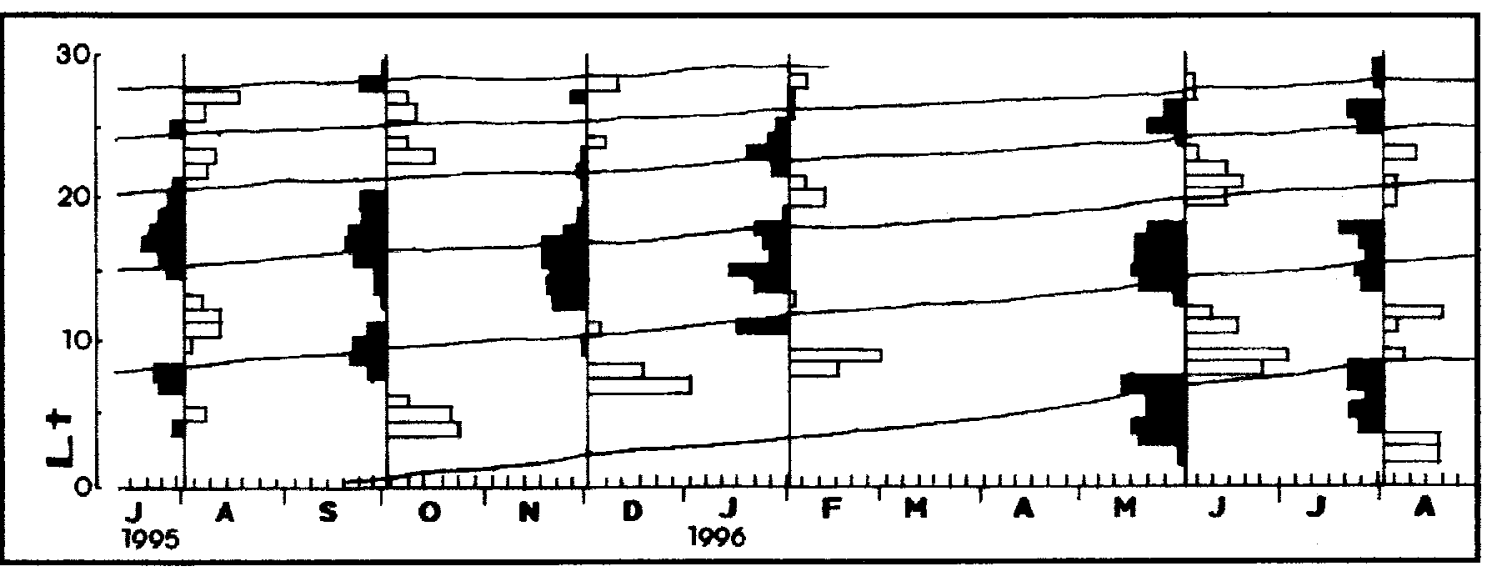

Fig. 5. Distribution of classes of total length restructured frequencies and seasonal growth curves of Porichthys porosissimus (by ELEFAN I) in southern Brazil. 
Table 2. Growth parameter estimates by ELEFAN I routine in Fisat for Porichthys porosissimus in southern Brazil.

$\begin{array}{cccccc}\mathrm{L} \propto(\mathrm{cm}) & \mathrm{K}\left(\text { year }^{-1}\right) & \mathrm{C} & \mathrm{WP} & \mathrm{Rn}\left(\times 10^{-3}\right) & \phi^{\prime} \\ 37.0 & 0.285 & 0.3 & 0.91 & 180 & 2.83 \\ 37.0 & 0.28 & - & - & 171 & 2.83\end{array}$

The length-weight relationship of the Atlantic midshipman was expressed by the equation: $\mathrm{W}_{\mathrm{t}}=$ $0.00498 \mathrm{~L}_{\mathrm{t}}^{3.148}\left(\mathrm{r}^{2}=0.941\right)$ and the $t$-test for parameter $b$ confirms the growth with positive alometry (calculated $t=8.398>$ critical $t, \mathrm{p}<0.05$ ). The relative condition factor $(\mathrm{Kn})$ for the species presented values higher than 1.0, considering significance tests for three bimonthly periods (September/October, January/February, July/August) (Fig. 6 and Tab. 3). Instantaneous mortality coefficients, exploitation rate and survival rate are shown in Table 4.

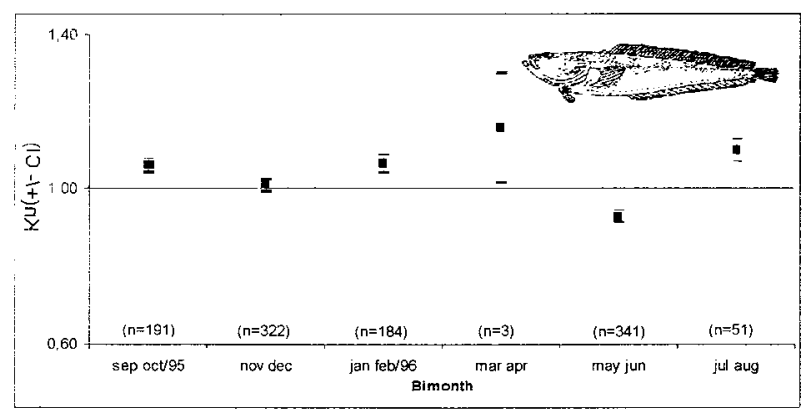

Fig. 6. Bimonth averages values of relative condition factor $(\mathrm{Kn})$ and confidence intervals $(\mathrm{CI})$ of Porichthys porosissimus. (excluding juveniles) in southern Brazil.
The ratios of the pink shrimp catches: Atlantic midshipman catches (Tab. 5) show higher catches for this latter species. Otherwise, these ratios registered considerable variation over the study period, due to the seasonal variation in the abundance of the Atlantic midshipman

\section{Discussion}

Porichthys porosissimus had high frequencies of occurrence throughout the year (Haimovici et al., 1996; Rocha, 1990; Natali-Neto, 1994). A relationship between the species and cold waters masses in the 20$50 \mathrm{~m}$ depth stratum, occupying the area dominated by South Atlantic Central Water and the transitional area with Coastal Water, was confirmed by Natali-Neto (1994). Along the Rio Grande do Sul coast $\left(28^{\circ}-33^{\circ} \mathrm{S}\right)$ the species has been reported in waters deeper than $26 \mathrm{~m}$ (Haimovici \& Habiaga, 1982; Haimovici et al., 1996). Due to this depth distribution model it may be suggested that $P$. porosissimus is of structural importance for the Ubatuba region and is related to the bottom type, having wide distribution in the area with no water mass dependence (Rossi-Wongtschowski \& Paes, 1993; Peria, 1995), contradicting Natali-Neto (op. cit.) for whom $P$. porosissimus occupies areas with cold waters under the direct influence of SACW. This may explain the deep strata occupied by this species and may also be used to explaining the variation in abundance recorded by Rocha (1990) - higher values in summer - and by Natali-Neto (op. cit.) - higher abundance in winter. In this study, the highest catches occurred at the end of spring and the lowest catches in winter, suggesting some relationship with SACW.

Table 3. Average values of relative condition factor $(\mathrm{Kn})$, confidence intervals $(\mathrm{Cl})$, standard deviations (Sd) and $\boldsymbol{t}$-tests for Porichthys porosissimus (excluding juveniles) in southern Brazil.

$\begin{array}{lllccccc} & \mathrm{Kn} & \mathrm{CI} & \mathrm{Sd} & \mathrm{N} & \mathrm{t} \text { calculate } & \mathrm{t} \text { critic } & \text { results } \\ \text { Sep-Oct } & 1.062 & 0.016 & 0.112 & 191 & 7.648 & 1.653 & \mathrm{Kn}>1.0^{*} \\ \text { Nov-Dec } & 1.011 & 0.014 & 0.129 & 322 & 1.546 & 1.650 & \mathrm{Kn}=1.0 \\ \text { Jan-Feb } & 1.066 & 0.024 & 0.165 & 184 & 5.391 & 1.653 & \mathrm{Kn}>1.0^{*} \\ \text { Mar-Apr } & 1.159 & 0.143 & 0.126 & 3 & 2.184 & 2.900 & \mathrm{Kn}=1.0 \\ \text { May-Jun } & 0.930 & 0.015 & 0.136 & 341 & 9.511 & 1.650 & \mathrm{Kn}<1.0 \\ \text { Jul-Aug } & 1.099 & 0.032 & 0.115 & 51 & 6.156 & 1.676 & \mathrm{Kn}>1.0^{*}\end{array}$

Table 4. Bimonthly relationship between pink shrimp and Porichthys porosissimus (in g) and general average (not including March-April) in southern Brazil.

$\begin{array}{ccccccc}\text { Sep-Oct } & \text { Nov-Dec } & \text { Jan-Feb } & \text { Mar-Apr } & \text { May-Jun } & \text { Jul-Aug } & \text { Average } \\ 1.28: 1 & 0.26: 1 & 0.49: 1 & 6.17: 1 & 0.80: 1 & 5.0: 1 & 0.67: 1\end{array}$


Table 5. Comparison of mortalities ratios estimates: total $(\mathrm{Z})$, natural (M), and fishing (F); and survival (S) among the present study and Peria's (1995) in southern Brazil.

\begin{tabular}{ccccccccc}
$Z$ B \& H & Z S \& & Z c cath & Z average & M Pauly & F & S & E & References \\
1.47 & 1.60 & 1.54 & 1.53 & 0.59 & 0.95 & 21.6 & 0.62 & Peria \\
2.29 & 2.46 & 1.75 & 2.17 & 0.62 & 1.55 & 11.4 & 0.71 & n. o. \\
2.33 & 2.45 & 1.64 & 2.14 & 0.63 & 1.51 & 11.8 & 0.71 & 0. \\
\hline
\end{tabular}

Obs.: Beverton \& Holt (B \& H), Ssentongo \& Larkin (S \& L) and catch curve (c. catch), non oscillatory (n. o.); oscillatory (o.).

Taking the pink shrimp as the target species, it is to be expected that fisheries should be undertaken in those areas in which it is most abundance.

The length composition and recruitment analysis are important for the characterization of the population structure. Peria (1995) studied the population dynamics of $P$. porosissimus off the South Brazilian coast and presented similar findings to those of the present contribution. The recruitment period was confirmed in winter, although the second recruitment period showed by that author in April was not observed in this study. Haimovici et al. (1996) suggested that the recruitment for the species was observed throughout year in the Rio Grande do Sul state, but not in this region. As shown by length composition, different population strata occupied the sampled area with the recruitment occurring in small batches during the year, though peaks may be seen in the early summer and winter.

The ELEFAN I and Wetherall methods are the best indicators for tropical species with low life cycle and quick growth (Isaac-Nahum, 1989), but the interpretation of the results depends on the sample size and the biological information regarding the species. Problems in estimating growth parameters employing length class distribution provided by commercial fishery landing data are due to a lack of information on the discarded portion of the specimens (Sparre \& Venema, 1992).

Analysing the results, the oscillatory growth pattern was considered to be closer to reality. This assumption differs from Peria's (1995) choice. Sparre \& Venema (1992) affirmed that oceanographic changes in tropical areas are reflected in seasonality of growth making it oscillatory. Avila-Silva (1996) attributes to the penetration of the SACW onto in the continental shelf the ring formation of the urohyal and scales of Pagrus pagrus of southeastern Brazil, reflected in the WP values which thus corroborate the methods adopted. On the other hand, Isaac-Nahum (1989) demonstrated that when oscillatory growth is not taken into consideration there is a resulting low variation among estimated values, as is also to be observed in this study (Tab. 4). The adoption of oscillatory growth shows better values for the fit of goodness index $(\mathrm{Rn})$. The best fit of goodness index was obtained by keeping the winter point (WP) earlier, which reduced the amplitude of oscillation (C) to 0.3 , indicating a lower variation in water temperature as between summer and winter. This behaviour makes sense when $P$. porosissimus is considered a subtropical species related to cooler water and as thus lessen influence of Coastal Water. Peria (1995) estimated seven (ELEFAN I) and six (Bhattacharya) age classes (attributed to the lowest number of sampled age classes of older specimens). The estimate for $\phi^{\prime}$ shows $L \infty$ and $K$ relationships as valid, with no discrepancies in the values registered, and similar to those estimated by Peria (op. cit.).

Table 6. Values of growth estimates for Porichthys porosissimus in southern Brazil.

$\begin{array}{ccccc}\text { Lo }(\mathrm{cm}) & \mathrm{K}\left(\text { year }^{-1}\right) & \text { Methods } & \operatorname{Rn}\left(10^{-3}\right) & \text { References } \\ 36.9 & 0.270 & \text { Elefan I n. o. } & 115 & \text { Peria (1995) } \\ 37.0 & 0.280 & \text { Elefan I n. o. } & 171 & \text { this paper } \\ 37.0 & 0.285 & \text { Elefan I o. } & 180 & \text { this paper }\end{array}$

The Atlantic midshipman shows a positive alometric growth, indicating a better application to the relative condition factor $(\mathrm{Kn})$.

The Atlantic midshipman shows two periods of high $\mathrm{Kn}$ values (winter and middle of summer). This may be indicative of partial spawning, but the peaks coincided with recruitment and the high value observed in summer with intense gonadal development. DeMartini (1990) registered a reproductive migration in early summer for the co-generic species $P$. notatus. The same may be suggested for $P$. porosissimus as the summer as the most intense reproductive period. If $\mathrm{Kn}$ values higher than 1.0 are taken to represent the period of highest gonadal development, the species spawns between November and February, the period with the largest food offer, high adult concentration and warmer coastal water. This spawning pattern was confirmed by Katsuragawa et al. (1993) who demonstrated the high egg abundance of several groundfish species in the Ubatuba region during the austral summer. The highest volume of ichthyoplankton in summer coincides with the SACW penetration into the coastal region, enhancing the availability of food for fish larvae. As this period is different from the 90 -day closed fishery 
season for shrimp between February and May, the reproductive behaviour suggests that commercial fisheries were having an impact on mature specimens of $P$. porosissimus.

The Atlantic midshipman, a species endemic to the Argentinian Zoogeographical Marine Province (Figueiredo, 1981), is replaced in the Caribbean by $P$. plectrodon, this latter is used as human food (Cervigon, et al., 1992). Figueiredo (op. cit.) reported only a few morphological differences between $P$. porosissimus and $P$. plectrodon and, for this reason, they are considered by some authors to be synonymous. This similarity suggests that discards are cultural, as pointed out by Haimovici \& Mendonça (1996). In São Paulo State, the species is one of the most abundant in the by-catch of the sea-bob shrimp fishery (Paiva-Filho \& Schmiegelow, 1986; Graça-Lopes, 1996) but they are entirely discarded. The lack of commercial value masks the high catches of the species in shrimp fishery. Vianna (1998) observed that $P$. porosissimus is the species with highest CPUE and relative numerical abundance. To Alverson et al. (1994), mortality estimates by discards are of importance because they furnish additional data on fishery mortality beyond that provided by the official landings. Total mortalities of the species obtained by Peria (1995) were higher than those of the present study, but as natural mortality must be quite similar, fishery mortality must be responsible for that increase. Avila-Silva (1996) interpreted the abrupt decrease in the abundance of the greater length classes as possibly due to fishery as mortality, but there is also a possibility that it may be related to their lesser vulnerability to fishing because of the seasonal migration of some individuals. This pattern was observed in the present study and probably the mortalities have been overestimated.

Vianna (1998) has observed an increase in the pink shrimp fleet over recent decades in the Ubatuba region. Values of exploitation rate over 0.5 indicate overexploitation (Pauly, 1983), thus demonstrating the deleterious fishery action on the population studied. Alverson et al. (1994) confirmed the impact caused by non intentional catches and this has different effects on each species in terms of reduced reproductive ratio, high parental aid and low natural mortality. As far small fish, due to their high mortality, other factors may impact growth and recruitment, resulting in significant losses in the by-catch population.

Discards of by-catch are of great importance, as pointed out in Agenda 21 (UNCED, 1992) and recent world-wide efforts have been made to monitor and reduce them (Alverson et al., 1994). There are many ways of reducing discards of Porichthys porosissimus and others fish, through stimulating the use of the production of by-products, adequate fishery policies, introduction of selectivity devices and the creation of exclusion zones for trawl fishing.

\section{Acknowledgements}

The authors thanks Drs. Alberto Peret and Nivaldo Nordi (UFSCar); Erica Caramaschi (UFRJ); Francisco M.S. Braga (Unesp) and Carmem RossiWongtschowski (IOUSP) by criticisms to the PhD thesis of the former author that originates this contribution. CAPES and CNPq for the scholarships to $M . V$., and two anonymous referees for useful comments to previous versions of the text.

\section{References}

Alverson, D. L.; Freeberg, M. H.; Pope, J. G. \& Murawski, S. A. 1994. A global assessment of fisheries by-catch and discards. FAO Fish. Tech. Pap., 339:1-233.

Avila-Silva, A. O. da 1996. Idade, crescimento, mortalidade e aspectos reprodutivos do Pargo, Pagrus pagrus (Teleostei: Sparidae), na costa do Estado de São Paulo e adjacências. Dissertação de mestrado. Universidade de São Paulo, Instituto Oceanográfico. 116p.

Beverton, R. J. H. \& Holt, S. J. 1956. A review of methods for estimating mortality rates in exploited fish populations, with special reference resources of bias in catch sampling. Rapp. P-v. Reún. Cons. Perm. Int. Explor. Mer, 140:67-83.

Castro Filho, B. M.; Miranda, L. B. de \& Miyao, S. Y. 1987. Condições hidrográficas na plataforma continental ao largo de Ubatuba: variações sazonais e em média escala. Bolm Inst. oceanogr., S Paulo, 35(2):135-151.

Cervigon, F.; Cipriani, R. \& Fischer, W. 1992. Guia de campo de las espécies comerciales marinas y de águas salobres de la costa septentrional de Sur América. Roma, FAO. 513p.

Coelho, J. A. P.; Puzzi, A.; Graça-Lopes, R.; Rodrigues, E. S. \& Prieto Jr., O. 1986. Análise da rejeição de peixes na pesca artesanal dirigida ao camarão sete-barbas (Xiphopenaeus kroyeri) no litoral do Estado de São Paulo. B. Inst. Pesca, São Paulo, 13(2):51-61.

DeMartini, E. E. 1990. Annual variations in fecundity egg size and condition of the plainfin midshipman (Porichthys notatus). Copéia, (3):850-855. 
Figueiredo, J. L. \& Menezes, N. A. 1978. Manual de peixes marinhos do sudeste do Brasil. II. Teleostei (1). Universidade de São Paulo, Museu de Zoologia. $110 \mathrm{p}$.

Figueiredo, J. L. 1981. Estudo das distribuições endêmicas de peixes da província zoogeográfica marinha argentina. Tese de doutorado. Universidade de São Paulo, Instituto de Biociências. 121 p.

Graça-Lopes, R. 1996. A pesca do camarão setebarbas Xiphopenaeus kroyeri Heller (1862) e sua fauna acompanhante no litoral do Estado de São Paulo. Tese de doutorado. Universidade Estadual Paulista, Instituto de Biociências de Rio Claro. $96 \mathrm{p}$.

Haimovici, M. \& Maceira, R. P. 1981. Observações sobre seleção a bordo e rejeição na pesca de arrasto de fundo no Rio Grande do Sul. In: CONGRESSO BRASILEIRO DE ENGENHARIA DE PESCA II. Recife, 1981. Anais. Recife, AEP. p.401-412.

Haimovici, M. \& Habiaga, R. P. 1982. Rejeição a bordo na pesca de arrasto de fundo no litoral do Rio Grande do Sul num cruzeiro de primavera. Doc. Tecn. FURG, 2:1-14.

Haimovici, M.; Martins, A. S. \& Vieira, P. C. 1996. Distribuição e abundância de peixes teleósteos demersais sobre a plataforma continental do sul do Brasil. Rev. Brasil. Biol., 56 (1):27-50.

Haimovici, M. \& Mendonça, J. T. 1996. Descartes da fauna acompanhante na pesca de arrasto de tangones dirigida a linguados e camarões na plataforma continental do sul do Brasil. Atlântica, Rio Grande, 18:161-177.

Isaac-Nahum, V. J. 1989. Analysis of methods for the estimation of fish growth parameters. based on data from the family Sciaenidae and on simulated data. Tese de doutorado. Universitat $\mathrm{Zu} \mathrm{Kiel,}$ Fakultat der Christian-Albrechts. 244p.

Katsuragawa, M.; Matsuura, Y.; Suzuki, K.; Dias, J. F. \& Spach, H. L. 1993. O ictioplancton ao largo de Ubatuba. SP: composição, distribuição e ocorrência sazonal (1985-1988). Publção esp. Inst. oceanogr., S Paulo, (10): 85-121.

LeCren, E. D. 1951. The length-weight relationship and seasonal cycle in gonad weight and condition in perch Perca fluviatilis. J. Anim. Ecol., 20(2):201-219.
Munro, J. L. \& Pauly, D. 1983. A simple method for comparing the growth of fishes and invertebrates. Fishbyte, 1 (1):5-6.

Natali-Neto, J. F. 1994. Ictiofauna do ecossistema tropical marinho de Ubatuba $\left(23^{\circ} 36^{\prime}-24^{\circ} 22^{\prime} \mathrm{S}\right.$; $44^{\circ} 33^{\prime}-45^{\circ} 08^{\prime}$ W). SP - Brasil, entre 50 e 100 metros de profundidade: composição, distribuição, abundância e diversidade. Dissertação de mestrado. Universidade de São Paulo, Instituto Oceanográfico. $2 \mathrm{v}$.

Paiva-Filho, A. M. \& Schmiegelow, J. M. M. 1986. Estudo sobre a ictiofauna acompanhante da pesca do camarão sete-barbas (Xiphopenaeus kroyeri) nas proximidades da Baía de Santos-SP. IAspectos quantitativos. Bolm Inst. oceanogr., S Paulo, 34:79-85.

Pauly, D. 1980. On the interrelationships between natural mortality. growth parameters and mean environmental temperature in the 175 fish stocks. J. Cons. Int. Explor. Mer, 39(2):175192.

Pauly, D. \& Martosubroto, P. 1980. The population dynamics of Nemipterus marginatus off Western Kalimantan, South China Sea. J. Fish Biol., $17(3): 263-273$.

Pauly, D. \& David, N. 1981. ELEFAN I, a BASIC program for the objective extraction of growth parameters from length-frequency data. Meeresforschung, 28(4):205-211.

Pauly, D. 1983. Some simple methods for the assessment of tropical fish stocks. FAO Fish. Tech. Pap., 234: 52p.

Pauly, D. 1986. On improving operation and use of the Elefan programs. Part. II. Improving the estimation of Lo. Fishbyte, 4(1):18-20.

Peria, C. G. 1995. Estimativa da taxa de produção e da relação produção-biomassa média (P-B) de peixes demersais do ecossistema costeiro de Ubatuba. SP. Brasil. Dissertação de mestrado. Universidade de São Paulo, Instituto Oceanográfico. 141p.

Rocha, G. R. A. 1990. Distribuição, abundância e diversidade da ictiofauna na região de Ubatuba-SP $\left(23^{\circ} 20^{\prime} \mathrm{S}-2^{\circ} 00^{\prime} \mathrm{S} ; 44^{\circ} 30^{\prime} \mathrm{W}\right.$ $\left.45^{\circ} 30^{\prime} \mathrm{W}\right)$, Brasil. Dissertação de mestrado. Universidade de São Paulo, Instituto Oceanográfico. 2v. 
Rossi-Wongtschowski, C. L. D. B. \& Paes, E. T. 1993. Padrões espaciais e temporais da comunidade de peixes demersais do litoral norte do Estado de São Paulo-Ubatuba. Brasil. Publção. esp. Inst. oceanogr., S Paulo, (10):169188.

Sparre, P. \& Venema, S. C. 1992. Introduction to tropical fish stock assessment. Part. 1. Manual. FAO Fish. Tech. Pap., 306: 376p.

Ssentongo, G. W. \& Larkin, P. A. 1973. Some simple methods of estimating mortality rates of exploited fish populations. J. Fish. Res. Bd. Can., 30(5):695-698.

UNCED. United Nations Conference on Environment and Development. 1992. Agenda 21. Cap. 17.
Vianna, M. 1998. Análise de populações de peixes teleósteos acompanhantes da pesca de arrasto do camarão-rosa (Penaeus brasiliensis e $P$. paulensis), em Ubatuba, SP: captura. crescimento e mortalidade. Tese de doutorado. Universidade Federal de São Carlos, PPG-ERN. $114 \mathrm{p}$.

Wetherall, J. A. 1986. A new method for estimating growth and mortality parameters from length frequency data. Fishbyte, 4 (1):12-14.

Zar, J. H. 1984. Biostatistical analysis. Englewood Cliffs, Prentice-Hall. 718p.

(Manuscript received 16 September 1999; revised 24 April 2000; accepted 07 December 2000) 